\title{
The role of the colostrum and milk in Neospora caninum transmission
}

\author{
B. MOSKWA, W. CABAJ
}

\author{
Witold Stefański Institute of Parasitology of the Polish Academy of Sciences, Warsaw, Poland
}

\begin{abstract}
Summary
Neospora caninum, an apicomplexan protozoan causes economical losses due to reproductive failure associated with abortion among cattle. The transmission of $N$. caninum is possible through vertical transmission in utero, or according to the modern nomenclature endogenous and exogenous infection modes and horizontal transmission through ingestion of oocysts. Limited data is available on the vertical transmission during suckling time, via colostrum and milk.

In this paper the main scientific aim focused on $N$. caninum DNA detection in the milk and colostrum of seropositive cows have been reviewed. In this term, the risk of animals and humans infection has been discussed.
\end{abstract}

Key words: Neospora caninum; vertical transmission; milk; colostrum; DNA; PCR

\section{Introduction}

Neospora caninum is an apicomplexan parasite, closely related to Toxoplasma gondii (Dubey, 1999; Holmdahl et al., 1994). This pathogenic intracellular parasite can infect warm-blooded vertebrates worldwide as dogs, cats, cattle, sheep, horses, rats, foxes, goats, alpacas, lamas, deer, camel, bison and other animals (Cabaj et al., 2004, 2005; Dubey, 2005; Dubey \& Dubey, 2003).

The infection causes important economical losses in cattle due to reproductive failure associated with abortion and mortality in congenitally infected calves (Anderson et al., 1995: Cabaj et al., 2000; Davison et al., 1999; Moskwa and Cabaj, 2003; Wouda et al., 1999).

Due to the specific localization of $N$. caninum in the brain, spinal cord and muscles, it is difficult to demonstrate the presence of the parasite by the direct methods (Dubey \& Lindsay, 1996; Peters et al., 2001). This renders the development of specific serological tests for parasite detection necessary (Björkman \& Uggla, 1999; Maley et al., 2001; Packman et al., 1998). Neospora caninum infection is diagnosed in post-mortem samples by the detection of parasites, parasite antigen or parasite DNA using histopathology, immunohistochemistry, and polymerase chain reaction (Hůrková-Hofmannová et al., 2006; Peters et al., 2001; Yamage et al., 1996). Molecular techniques such as PCR offer a highly sensitive and specific alternative to immunological methods for the diagnosis of neosporosis. Using this method the presence of $N$. caninum DNA was confirmed in different tissues such as brain, spinal cord and muscle (Guy et al., 2001; Sager et al., 2003; Wiśniewski et al., 2002). In living animals, the presence of specific antibodies and DNA in serum, milk and semen indicates the possibility of the parasite infection (Björkman et al., 1997; Chanlun et al., 2002; Moskwa et al., 2003; OrtegaMora et. al., 2003; Schares et al., 2004, 2005; SerranoMartinez et al., 2007; Varcasia et al., 2006).

\section{Sources of transmission}

The transmission of $N$. caninum is possible through vertical route in uterus, or according to the modern nomenclature endogenous and exogenous infection modes and horizontal infection (Trees \& Williams, 2005). The probability that infected cattle will pass the infection to their offspring during gestation is very high $(81-100 \%)$ (Pare et al., 1996). The horizontal transmission occurs through ingestion of oocysts, tachyzoites or tissue cysts (Anderson et al., 1997; Dijkstra et al., 2002; Pare et al., 1996; Schares \& Conraths, 2001). Consumption of placenta, material of aborted foetuses or uterine discharge in combination with defecation on the feeding alley, storage of the grass or corn silage was observed in $75 \%$ of the post-natally infected farms (Dijkstra et al., 2002). The ingestion of carcasses of infected animals with cysts in the muscle is suspected in $N$. caninum sylvatic transmission cycle (Dubey, 2003).

Limited data is available on the vertical transmission during suckling time.

The data of Uggla et al. (1998) have shown that oral infection with $N$. caninum via colostrum might be a possible 
route of vertical transmission resulting in the infection of newborn calves within the first few hours of their life. Although a previous study done by Dubey et al. (1998) indicated that $N$. caninum tachyzoites may not be resistant to HCL-pepsin.

Subsequently, Dijkstra et al. (2001) revealed that dogs shed $N$. caninum oocysts after ingestion of naturally infected bovine placenta but not after ingestion of colostrum spiked with tachyzoites. The authors concluded that may be possible that tachyzoites incorporated in placenta passage the stomach before being destroyed by HCL-pepsin. The work of Davison et al. (2001) showed that calves can be infected with $N$. caninum by the oral route with experimentally inoculated colostrum or milk repleacer, even one week after birth. However, studies performed by Davison et al. (2001) revealed that cattle were not infected when given milk or colostrum from dams naturally infected with $N$. caninum, showing no evidence of $N$. caninum tachyzoites or parasite DNA in the tissues of experimental animals. There may be wide variation in the number of parasites present in milk both between individual cows and at different stages of lactation. The authors summarized that in some situation calves may potentially become infected via this route, if for example large numbers of tachyzoites were present in the colostrum or milk in an individual cow.

\section{Neospora caninum DNA demonstration}

The earlier results implicated to examine colostrum and the milk samples from seropositive cows to demonstrate the presence of parasite DNA. This study was done in cows with a history of abortion. Sera of these animals were tested for the presence of $N$. caninum-specific IgG using a commercially available ELISA test kit (IDEXX Laboratories, Inc., Westerbrook, Maine, USA), using an automated plate reader EL*800, Bio-tek, Instruments Inc.

Colostrum samples and the milk samples were collected from seropositive cows and prepared to the further analysis according to Chanlum et al. (2002), with some modifycations (Moskwa et al., 2003). Colostrum samples were collected on calving day and the day after.

The skimmed colostrum and milk samples (sediment) were collected for PCR analysis (Moskwa et al., 2003, 2007). Briefly $\div$ genomic DNA was isolated from tachyzoites of the reference strain $\mathrm{NC}-1$, the colostrum and milk sediments using the Nucleospin ${ }^{\circledR}$ Tissue DNA extraction kit (Macherey-Nagel, Germany).

The reagents used for PCR were purchased from Fermentas (MBI Fermentas,USA).

The Nc5 region was selected as the target sequence for DNA amplification. Primers Np6 and Np21, spanning a $328 \mathrm{bp}$ region, were produced according to Yamage et al. (1996).

Briefly, PCR was performed in a final volume of $50 \mu \mathrm{l}$ mixture containing $5 \mu \mathrm{l}$ of 10x PCR buffer (MBI Fermentas, USA), $0.2 \mathrm{mM}$ of each dNTP, 10 pmol each of $N$. $c a-$ ninum primer Np6 and Np21 and $1 \mathrm{U}$ Taq DNA polymerrase. Amplification was carried out in a thermal cycler (Genius, Techne) using 30 cycles with denaturation $\left(94^{\circ} \mathrm{C}\right.$,
$20 \mathrm{sec})$, annealing $\left(55^{\circ} \mathrm{C}, 30 \mathrm{sec}\right)$ and primer extension $\left(72^{\circ} \mathrm{C}, 25 \mathrm{sec}\right)$. After the last cycle, additional extension was applied for $10 \mathrm{~min}$ at $72^{\circ} \mathrm{C}$.

Two negative controls (water and DNA isolated from seronegative dams) and a positive control (DNA from the NC1 isolate) were included in each reaction.

Amplification products were analyzed by electrophoresis through a $1 \%$ agarose gel stained with ethidium bromide and visualised under UV light using the Kodak Electrophoresis Documentation and Analysis System (EDAS) 290.

The PCR assay yielded the expected $328 \mathrm{bp}$ product in milk and colostrum samples from seropositive cows collected on calving day and one day after (Moskwa, 2004; Moskwa et al., 2003, 2003a; 2007). No amplification was observed in milk and colostrum samples collected from seronegative cows.

It seems that there is possibility that $N$. caninum tachyzoites present in milk and colostrum may be transmitted to other noninfected young calves by feeding them of pooled colostrum and milk, which is a common husbandry practise in dairy farms in the UK (Davison et al., 2001).

\section{Risk for humans}

Another very important consideration is whether N. caninum may be infective for humans. This risk seems to be higher for consumption of raw milk from an individual cows, contrary to the consumption of the bulk tank milk in which the parasites would be greatly diluted (Davison et al., 2001). Several studies have not revealed the evidence of $N$. caninum infection in human (Graham et al., 1999; Petersen et al., 1999). But the data of Nam et al. (1998) revealed that twelve cases out of 172 Toxoplasma-positive sera cross reacted with $N$. caninum antigens, and one of 110 Toxoplasma-negative sera. The studies done by Tranas et al. (1999) revealed that $6.7 \%$ of 1209 human blood donors were found to be seropositive. Another at-tempt to investigate the presence of human neosporosis was performed with the different groups of human popu-lation in Brazil (Lobato et al., 2006). Antibodies against $N$. caninum were predominantly detected in HIV-infected patients $(38 \%)$, patients with neurological disorders $(18 \%)$ and newborns (5\%).

Our earlier study was done to investigate the influence of some exogenous and endogenous factors on the viability and growth of tachyzoites of $N$. caninum as well as their virulence in an in vitro system. Tachyzoites were incubated in milk from both positive and seronegative cows (at + $4^{\circ} \mathrm{C}$ ). Only after 1 day of incubation in milk from seronegative cow tachyzoites were alive and able to invade the monolayer Vero cells. After 21 days of incubation in PBS $\left(\right.$ at $\left.+4{ }^{\circ} \mathrm{C}\right)$, all parasites were viable and able to grow and invade Vero cells. After freezing $\left(-20^{\circ} \mathrm{C}\right)$, heating $\left(+100^{\circ} \mathrm{C}\right)$ and sterilization, the devitalization of all tachyzoites was observed. Only UV- treated parasites retained their vitality in the cell culture (Moskwa et al., 2005).

However, the limited data is still known about the epidemiology of $N$. caninum infection in humans, the risk of infection seems to be higher for consumption of the milk 
straight from the cow. Results have indicated that nonhuman primates (rhesus macaque) are susceptible to $N$. caninum infection (Barr et al., 1994).

This article was not independently peer-reviewed and is published as submitted by the author.

\section{References}

Anderson, M. L., Palmer, C. W., Thurmond, M. C. (1995): Evaluation of abortions in cattle attributable to neosporosis in selected dairy herds in California. J. Am. Vet. Med. Assoc., 207: $1206-1210$

Anderson, M. L., Reynolds, J. P., Rowe, J. D., SverLOW, K. V., PACKhaM, A. E., BARr, B. C., CONRAD, P. A. (1997): Evidence of vertical transmission of Neospora sp. infection in dairy cattle. J. Am. Vet. Med. Assoc., 210: 1169 $-1172$

Barr, B. C., Conrad, P. A., Sverlow, K. W., Tarantal, A. F., HENDRICKX, A. G. (1994): Experimental fetal and transplacental Neospora infection in the nonhuman primate. Lab. Investig., 71:214-221

BJÖRKMAN, C., HOLMHDAHL, O. J. M., UGGlA, A. (1997): An indirect enzyme-linked immunoassay (ELISA) for demonstration of antibodies to Neospora caninum in serum and milk of cattle. Vet. Parasitol., 68: $251-260$

BJÖRKMAN, C., UGGLA, A. (1999): Serological diagnosis of Neospora caninum infection. Int. J. Parasitol., 29: 1497 $-1507$

Cabaj, W., Choromański, L., Rodgers, S., Moskwa, B., MALCZEWSKI, A. (2000): Neospora caninum infections in aborting dairy cows in Poland. Acta Parasitol., 45: 113 114

Cabaj, W., Moskwa, B., Pastusiak, K., Gill J. (2004a): Antibodies to Neospora caninum in the blood of European bison (Bison bonasus bonasus L.) living in Poland. COST - Action 854 "Protozoal reproduction losses in farm ruminants". Joint Meeting of Working Groups 2 and 3 "New aspects on transmission and diagnosis of ruminant protozoal abortificients", Derio, Spain, June 17 - 19, 10

Cabaj, W., Moskwa, B., Pastusiak, K., Gill, J. (2005): Antibodies to Neospora caninum in the blood of European bison (Bison bonasus bonasus L.) living in Poland. Vet Parasitol., 128: 163 - 168

Chanlun A., Näslund K., Aiumlamaid S., BJÖrKman C. (2002): Use of bulk milk for detection of Neospora caninum infection in dairy herds in Thailand. Vet. Parasitol., 110: $35-44$

Davison, H. C., French, N. P., Trees, A. J. (1999): Herdspecific and age-specific seroprevalence of Neospora caninum in 14 British dairy herds. Vet. Rec., 144: $547-550$

Davison, H. C., GuY, C. S., McGarry, J. W., GuY, F., Willams, D. J. L., Kelly, D. F., Trees, A. J. (2001): Experimental studies on the transmission of Neospora caninum between cattle. Res. Vet. Sci., 70: $163-168$

Dijkstra, Th., Eysker, M., Schares, G., Conraths, F. J., Wouda, W., Barkema, H. W. (2001): Dogs shed Neospora caninum oocysts after ingestion of naturally in- fected bovine placenta but not after ingestion of colostrum spiked with Neospora caninum tachyzoites. Int. J. Parasitol., 31: $747-752$

Dijkstra, Th., BARKema, H. W., Eysker, M., HesselinK, J.W., WOUDA, W. (2002): Natural transmission routes of Neospora caninum between farm dogs and cattle. Vet. Para-sitol., 105: 99 - 104

DubeY, J. P. (1999): Recent advances in Neospora caninum and neosporosis. Vet. Parasitol., 84: 349 - 367

Dubey, J. P., Dubey J. (2003): Review of Neospora caninum and neosporosis in animals. Korean J. Parasitol., 41: $1-16$

DuBEY, J. P. (2005): Life cycle and biology of Neospora caninum. Wiad. Parazytol., 57 - 58

DUBEY, J. P., LindSAY, D. S. (1996): A review of Neospora caninum and neosporosis. Vet. Parasitol., 67: 1 - 59

Dubey, J. P., Lindsay, D. S., SpeER, C. A. (1998): Structures of Toxoplasma gondii tachyzoites, bradyzoites, and sporozoites and biology of tissue cysts. Clin. Microbiol. Rev., 11: $267-299$

Graham, D. A., Calvert, V., Whyte, M., Marks, J. (1999): Absence of serological evidence for human Neospora caninum infection. Vet. Rec., 144: $672-673$

GuY, C. S., Williams, D. J. L., Kelly, D. F., McGarry, J. W., Guy, F., Buörkman, C., Smith, R. F., Trees, A. J. (2001): Neospora caninum in persistently infected, pregnant cows: spontaneous transplacental infection is associated with an acute increase in maternal antibody. Vet. Rec., 149: $443-453$

HŮRKOVÁ-HofMANNOVÁ, L., VÁClAVEK, P., ŠKORIČ, M., FICTUM P., MODRÝ, D. (2007): Multimammate rat (Mastomys natalensis), Tristram's jird (Meriones tristrami) and Wagner's gerbil (Gerbillus dasyurus) as laboratory models of acute neosporosis. Res. Vet. Sci., 82: $377-381$ Holmdahl, O. J., Mattsson, J. G., Uggla, A., JoHANSSON, K. E. (1994): The phylogeny of Neospora caninum and Toxoplasma gondii based on ribosomal RNA sequences. FEMS Microbiol. Lett., 119: 187 - 192

Labato, J., Silva, D. A. O., Mineo, T. W. P., Amaral, J. D. H. F., Silva Segundo, G. R., Costa-Cruz, J. M., Ferreira, M. S., Borges, A. S., Mineo, J. R. (2006): Detec-tion of immunoglobulin $\mathrm{G}$ antibodies to Neospora caninum in humans: high seropositivity rates in patients who are infected by human immunodeficiency virus or have neurological disorders. Clin. Vacc. Immunol., 13: 84 $-89$

Maley, S. W., Buxton, D., Thompson, K. M., SchrieFER, CH. E. S., INNES, E. A. (2001): Serological analysis of calves experimentally infected with Neospora caninum: a 1-year study. Vet. Parasitol., 96: 1 - 9

MoskwA, B. (2004): Colostrum as a source of Neospora caninum transmission? COST 854 - Annual Conference, "Protozoal reproduction losses in farm ruminants", (including joint workshop with COST 857 WG2), "Analysis of Organellar Proteosomes", Liverpool, United Kingdom, 7 9 September 2004, 10 - 11

Moskwa, B., CABAJ, W. (2003): Neospora caninum: a newly recognised agent causing spontaneous abortion in 
Polish cattle. Vet. Med., 59: 23 - 26

Moskwa, B., Cabaj, W., Pastusiak, K., BieŃ, J. (2003): The suitability of milk in detection of Neospora caninum infection in cows. Acta Parasitol., 48: 138 - 141

Moskwa, B., Cabaj, W., Pastusiak, K., Bień, J. WoJDAN, J., SLONIEWSKI, K. (2003a): The suitability of milk in detection of Neospora caninum infections in cows. COST 854, "Protozoal reproduction losses in farm ruminants", Joint Meeting of Working Groups 3 (Diagnosis) and 4 (Epidemiology, risk assessments, economic and control) Rheinsberg, Germany, 26 - 28 May 2003, 9

Moskwa, B., CabaJ, W., Pastusiak, K., BieŃ, J. (2005): Current studies on neosporosis in Poland. Wiad. Parazytol., 51: supp., $65-67$

Moskwa, B., Pastusiak, K., Bień, J., CABAJ, W. (2007): The first detection of Neospora caninum DNA in the colostrum of infected cows. Parasitol. Res., 100: 633 - 636

NAM, H., KANG, S., CHOI, W. (1998): Antibody reaction of human anti-Toxoplasma gondii positive and negative sera with Neospora caninum antigens. Korean J Parasitol., 36: $269-275$

Ortega-Mora, L. M, Ferre, I., Del-Pozo, I., CAetanoDA-Silva, A., Collantes-FernandeZ, E., REgIDOR-CERRillo, J., Ugarte-Garagalza, C., Aduriz, G. (2003): Detection of Neospora caninum in semen of bulls. Vet. Parasitol., 117: $301-308$

Packhman, A. E., Sverlow, K. W., Conrad, P. A., Loomis, E. F., Rowe, J. D., ANDerson, M. L., MARsh, A. E., CRAY, C., BARR, B. C. (1998): A modified agglutination test for Neospora caninum: development, optimalization, and comparison to the indirect fluorescent-antibody test and enzyme-linked immunosorbent assay. Clin. Diagn. Lab. Immunol.. 5: $467-473$

Pare, J., Thurmond, M. C., Hietala, S. K. (1996): Congenital Neospora caninum infection in dairy cattle and associated calfhood mortality. Can. J. Vet. Res., 60: 133 139

Peter, M., LÜtkefels, E., Heckeroth, A. R., Schares, G. (2001): Immunohistochemical and ultrastructural evidence for Neospora caninum tissue cysts in skeletal muscles of naturally infected dogs and cattle. Int. J. Parasitol., 31: $1144-1148$

Petersen, E., Lebech, M., Jensen, L., Lind, P. Rask, M., BAGger, P., BJÖRKMAN, C., UGGLA, A. (1999): Neospora caninum infection and repeated abortions in humans. Emerg. Infect. Dis., 5: $278-281$

SAGER, H., GloOR, M., BJÖRKMAN, C., KritzNER, S., GotTsteIN, B. (2003): Assessment of antibody avidity in aborting cattle by somatic Neospora caninum tachyzoites antigen IgG avidity ELISA. Vet. Parasitol., 112: $1-10$ Schares, G, BarWald, A, Staubach, C, Wurm, R, RAuser, M, CONRATHS, F. J, SCHROEDER, C. (2004): Adaptation of a commercial ELISA for the detection of antibodies against Neospora caninum in bovine milk. Vet. Parasitol. 120: 55 - 63

Schares, G., BArwald, A., Conraths, F. J. (2005): Adaptation of a surface antigen-based ELISA for the detection of antibodies against Neospora caninum in bovine milk. J. Vet. Med. Series B-Infectious diseases and veterinary public health, 52: $45-48$

SCHARES, G., CONRATHS, F. J. (2001): Placentophagia - an alternative way for horizontal transmission of Neospora caninum in cattle? Trends Parasitol., 17: 574

Serrano-Martinez, E., Ferre, I., Osoro, K., Aduriz, G., Mota, R.A., Martinez, A., Del-Pozo, I., Hidalgo, C.O., ORTEGA-MORA, L. M. (2007): Intrauterine Neospora caninum inoculation of heifers and cows using contaminated semen with different numbers of tachyzoites. Theriogenology, 67: 729 - 737

Tranas, J., Heinzen, R. A., Weiss, L. M,. McAllister, M. M. (1999): Serological evidence of human infection with the protozoan Neospora caninum. Clin. Diag. Lab. Immunol., 6: $765-767$

Trees, A. J., Williams, D. J. (2005): Endogenous and exogenous transplacental infection in Neospora caninum and Toxoplasma gondii. Trends Parasitol.,_21: $558-61$

Yamage, M., Flechtner, O., Gottstein, B. (1996): Neospora caninum: specific oligonucleotide primers for the detection of brain "cyst" DNA of experimentally infected nude mice by the polymerase chain reaction (PCR). $J$. Parasitol., 82: $272-279$

UgGla, A., Stenlud, S., Holmadahl, O.J.M., JaKuBeK, E.B., THEBO, P., KINDAHL, H., BJÖRKMAN C. (1998): Oral Neospora caninum inoculation of neonatal calves. Int. J. Parasitol., 28: 1467 - 1472

WiŚNiEWSKI, M., CABAJ, W., MOSKWA, B., WĘDRYCHOWICZ, H. (2002): The first detection of Neospora caninum DNA in brains of calves in Poland. Acta Vet., (Beograd) 52: $393-400$

Wouda, W., Bartels, C. J. M., Moen, A. R. (1999): Characteristics of Neospora caninum-associated abortion storms in dairy herds in The Netherlands (1995 to 1997). Theriogenology, 52: $233-245$

Varcasia, A., Capelli, G., Ruiu, A., Ladu, M., Scala, A., BJORKMAN, C. (2006): Prevalence of Neospora caninum infection in Sardinian dairy farms (Italy) detected by iscom ELISA on tank bulk milk. Parasitol. Res., 98: 264 267 